\title{
Bromocriptine Inhibits Pro-opiomelanocortin mRNA and ACTH Precursor Secretion in Small Cell Lung Cancer Cell Lines
}

\author{
W. E. Farrell, ${ }^{*}$ A. J. L. Clark, ${ }^{\star}$ M. F. Stewart, ${ }^{3}$ S. R. Crosby, ${ }^{\star}$ and A. White ${ }^{*}$ \\ ${ }^{*}$ Department of Medicine, University of Manchester, Hope Hospital, Salford M6 8HD, United Kingdom; ${ }^{\ddagger}$ Department of Clinical \\ Pathology, Manchester Royal Infirmary, Manchester M13 9WL, United Kingdom; and ${ }^{\S}$ Endocrine \& Reproduction Research Branch, \\ National Institutes of Health, Bethesda, Maryland 20892
}

\begin{abstract}
We have previously reported that a human small cell lung cancer (SCLC) cell line (COR L103) that expresses the proopiomelanocortin (POMC) gene and secretes ACTH precursor peptides is relatively resistant to glucocorticoid regulation. Using this model, we have now examined alternative regulatory mechanisms of the POMC gene and found that both the mRNA and ACTH precursor peptides were stimulated four- and twofold, respectively, after $48 \mathrm{~h}$ incubation with db-cAMP. Next, we examined the dopamine agonist, bromocriptine, which acts predominantly through $D_{2}$ receptors linked to adenyl cyclase to cause a reduction in intracellular cAMP. Bromocriptine suppressed cAMP levels and inhibited precursor peptide secretion within $24 \mathrm{~h}$ in a dose-dependent manner $(0.15-15 \mu \mathrm{M})$. At the highest dose, peptide secretion was inhibited from 95 to 53 $\mathrm{pmol} / \mathrm{mg}$ protein, and POMC mRNA was reduced by $\mathbf{5 0 \%}$, while $\beta$-actin mRNA remained unchanged. This effect could not be mimicked by incubation of cells with the $\alpha$-adrenergic antagonist, phenoxybenzamine, suggesting that the $\alpha$-adrenergic effects of bromocriptine were not responsible for this observation. These cells also secrete estradiol, but the secretory rate was unaffected by bromocriptine, suggesting, with the $\beta$-actin data, that the POMC inhibition was not a cytotoxic effect. No recovery in precursor peptide secretion was seen in a 48-h period after the removal of bromocriptine. However, when the postchallenge incubation was extended to $8 \mathrm{~d}$, there was a recovery in secretory potential between day 3 and day 8 and normal growth kinetics in the $4 \mathrm{~d}$ after removal of the drug. In contrast to these findings, the mouse corticotroph cell line, AtT20, showed no response to bromocriptine, in keeping with reports that this agonist has no effect on anterior lobe corticotrophs. We conclude that bromocriptine effectively inhibits POMC expression in SCLC cells, and that this phenomenon might be of useful clinical application. (J. Clin. Invest. 1992. 90:705-710.) Key words: bromocriptine - pro-opiomelanocortin • ectopic • small cell lung cancer
\end{abstract}

This work was presented in part at the 73rd Annual Meeting of the American Endocrine Society, June 1991, and was published in abstract form at that meeting (Abstr. 877).

Address correspondence and reprint requests to Anne White, Ph.D., Department of Medicine, University of Manchester, Hope Hospital, Eccles Old Road, Salford M6 8HD, United Kingdom.

Received for publication 13 August 1991 and in revised form 13 February 1992.

J. Clin. Invest.

(c) The American Society for Clinical Investigation, Inc.

$0021-9738 / 92 / 09 / 0705 / 06 \$ 2.00$

Volume 90, September 1992, 705-710

\section{Introduction}

Cushing's syndrome continues to pose difficulties in diagnosis and management despite the advent in recent years of corticotropin-releasing factor $(\mathrm{CRF})^{1}$ testing and sophisticated venous sampling and imaging techniques. Many of these difficulties center around the ectopic ACTH syndrome, in which $\mathrm{ACTH}$ is secreted by an extrapituitary tumor. Characteristically, POMC gene expression and ACTH secretion is unaltered by glucocorticoids, in contrast to corticotroph adenomas of the pituitary (1). In addition, limited processing of POMC results in the secretion of high molecular weight precursor forms of ACTH (2). We have recently described a human small cell lung cancer (SCLC) cell line which secretes POMC and pro$\operatorname{ACTH}(3,4)$ and is resistant to glucocorticoid regulation of POMC gene expression and peptide secretion, thus mimicking the in vivo findings (4) and behaving as a model of human ectopic ACTH production.

In the normal pituitary, CRF stimulates cAMP accumulation, which in turn results in increased POMC gene expression and peptide secretion. Resistance to CRF in ectopic ACTH secreting tumors is generally assumed to be due to the absence of $\mathrm{CRF}$ receptors, although there is no evidence as to whether the adenyl cyclase/cAMP signaling system is intact. It is possible that stimulation of this system by other receptors that modulate cAMP could provide new diagnostic tests for the condition. In addition, inhibition of the system by other agents that act through cyclase inhibitory receptors could provide alternative therapeutic options.

We have therefore tested the response of POMC gene expression and peptide secretion to cAMP in SCLC cell lines. As we will show, cAMP remains an effective stimulus of POMC gene expression, and thus we have investigated whether one agent, the dopamine agonist bromocriptine, which acts primarily through D2 receptors to inhibit cAMP production is an effective suppressor of POMC.

\section{Methods}

Cell culture. The COR L 24 and COR L103 cell lines were derived from patients with pathologically confirmed SCLC and were generously given to us by Dr. P. Twentyman, Cambridge, UK. The cells were grown as previously described (4), using RPMI 1640 (Gibco, Paisley, Scotland ) and supplemented with $2.5 \%$ fetal calf serum, human transferrin $(10 \mu \mathrm{g} / \mathrm{ml})$, bovine insulin $(5 \mu \mathrm{g} / \mathrm{ml})$, sodium selenite $\left(3 \times 10^{-8}\right.$ $\mathrm{M})$, Hepes buffer ( $10 \mathrm{mM})$, glutamine ( $4 \mathrm{mM})$, and sodium pyruvate $(1 \mathrm{mM})$. Antibiotics were not used. Incubation was at $37^{\circ} \mathrm{C}$ in an

1. Abbreviations used in this paper: CRF, corticotropin-releasing factor; GRP, gastrin-releasing peptide; MOPS, 3-(N-morpholino) propanesulphonic acid; POMC, pro-opiomelanocortin; SCLC, small cell lung cancer. 
atmosphere of $5 \% \mathrm{CO}_{2}$. The relatively long doubling times of these cell lines $(\sim 4 \mathrm{~d})$ in culture and their growth as floating aggregates limited the number of cultures that could be used in some experiments. AtT20 cells were cultured as described (5) in Ham's F10 medium (Flow Laboratories, Inc., McLean, VA) supplemented with horse serum (15\%), fetal calf serum $(2.5 \%)$, and glutamine $(4 \mathrm{mM})$ in an atmosphere of $5 \%$ $\mathrm{CO}_{2}$ at $37^{\circ} \mathrm{C}$.

Experimental design. Cells were grown to stationary phase and then passaged in one quarter vol fresh medium to generate three flasks of cells, all at the same cell density and stage of growth. Bromocriptine (Sandoz, AG, Basel, Switzerland), phenoxybenzamine (Smith Kline \& French Laboratories, Philadelphia, PA) and db cAMP (Sigma Chemical Co., St. Louis, MO) were initially prepared as concentrated stock solutions in DMSO, such that the concentration of solvent did not exceed $0.1 \%$ in test cultures. Controls received an equal volume of vehicle alone. All incubations were performed in triplicate. For the second messenger studies, cell pellets from each time point were combined for RNA extraction because of the limitations imposed by slow cell growth. Harvesting of cells at the end of the experiment involved assessment of cell viability by trypan blue exclusion, removal of a 0.5 $\mathrm{ml}$ sample of the cell suspension for protein analysis and pelleting of the cells which were then flash frozen and stored at $-70^{\circ} \mathrm{C}$ for RNA preparation. The culture medium was frozen and retained for measurement of ACTH precursor peptides and estradiol.

Studies of withdrawal of bromocriptine challenge. Culture medium was removed and flash frozen $24 \mathrm{~h}$ after challenge with bromocriptine $(15 \mu \mathrm{M})$. Cells were washed extensively in PBS three times and recultured in the same volume of fresh culture medium and sampled 24 and $48 \mathrm{~h}$ later. Longer term studies were essentially the same except that cells were seeded at one quarter the density post challenge and washing.

Immunoradiometric assay for precursor peptides. The development of the precursor assay is described in detail elsewhere (6). mAb $1 \mathrm{~A} 12$ (specific for ACTH 10-18) was radioiodinated, and mAb $1 \mathrm{C} 11$ (specific for gamma-MSH) was coupled to Sephacryl S300 as solid phase. Binding of both antibodies is required to generate a signal. The POMC standard was prepared from growth medium of a cultured human pituitary tumor by purification of the peptides using Sephadex G-75 chromatography under acid dissociating conditions. Standards were prepared at concentrations of $0-2600 \mathrm{pmol} / \mathrm{liter}$. The assay sensitivity is $2.6 \mathrm{pmol} /$ liter, and the within and between assay CVs are $<10 \%$ between $20-2,600 \mathrm{pmol} /$ liter and $37-2,600 \mathrm{pmol} /$ liter, respectively. The assay measures POMC and pro-ACTH but does not distinguish between them. Other POMC derived peptides (e.g., ACTH, betalipotrophin and $N$-propiocortin) are not recognized.

RIA of estradiol. Estradiol was measured in ether extracted culture medium by an "in-house" RIA employing double antibody separation. The antiserum had cross-reactivities of: $17 \beta$ estradiol, $100 \%$; oestrone, $2 \%$; oestriol $2 \%$; and progesterone, $<0.1 \%$. The estradiol RIA had a limit of detection of $116 \mathrm{pmol} / \mathrm{liter}$, and an intra and interassay coefficient of variation of 9.8 and $12.4 \%$, respectively.

cAMP measurement. These were performed on cell extracts using a commercially available kit (Amersham International, Amersham, UK) that gave a sensitivity of $25-1,600 \mathrm{fmol} /$ tube.

RNA preparation. Total cellular RNA was prepared by the method of Chomozynski and Sacchi (7). In brief, cell pellets were homogenized from frozen in $4 \mathrm{M}$ guanidinium thiocyanate, $25 \mathrm{mM}$ sodium citrate, $0.5 \%$ sarcosyl, and $0.1 \mathrm{M} 2$-mercaptoethanol by repeated excursions through a $0.8 \mathrm{~mm}$ hypodermic needle. After sequential addition of $0.2 \mathrm{M}$ sodium acetate (final concentration) and phenol chloroform $(1: 0.2)$ samples were centrifuged at $10,000 \mathrm{~g}$ for $20 \mathrm{~min}$ at $4^{\circ} \mathrm{C}$. The aqueous phase was precipitated with 1 vol of Isopropanol resuspended in $4 \mathrm{M}$ guanidinium thiocyanate and subject to reprecipitation before washing and drying. RNA was resuspended in water and quantitated by measurement of the absorption at $260 \mathrm{nM}$.

Quantitative RNA analysis. 5- $\mu \mathrm{g}$ aliquots of each RNA sample were applied to nylon backed nitrocellulose filters (Hybond C Extra; Amersham International) using a slot blot apparatus (Gibco BRL Grand Island, NY). Blots were hybridized at moderately high stringency ( $50 \%$ formamide at $42^{\circ} \mathrm{C}$ ) to the DNA probes described below. After hybridization for $16 \mathrm{~h}$, the filters were washed 5 times at $42^{\circ} \mathrm{C}$ in $2 \times$ standard saline citrate (SSC). $(1 \times$ SSC is $0.15 \mathrm{M}$ sodium chloride, $0.015 \mathrm{M}$ sodium citrate), $0.1 \%$ SDS and then twice in $0.2 \times$ SSC, $0.1 \%$ SDS, and finally twice at high stringency $0.1 \times \mathrm{SSC}, 0.1 \% \mathrm{SDS}$ at $42^{\circ} \mathrm{C}$. Autoradiography was carried out at $-70^{\circ} \mathrm{C}$ with image intensifying screens and Kodak XAR-5 film, for intervals ranging from 1 to $5 \mathrm{~d}$ in order to obtain a suitably contrasted image with each of the probes used. Autoradiographs were quantitated with a dual wavelength densitometer (CS 9,000; Shimadzu Corp., Kyoto, Japan), and all results are expressed relative to the $\beta$-actin mRNA as a control for the quality and quantity of RNA applied to the blot.

Northern blot analysis. Total cellular RNA was separated by electrophoresis $(2 \mathrm{~V} / \mathrm{cm}$ for $15 \mathrm{~h})$ on $1.4 \%(\mathrm{wt} / \mathrm{vol})$ agarose/formaldehyde $(6.5 \% \mathrm{vol} / \mathrm{vol})$ gels run in $20 \mathrm{mM} \mathrm{3-}(N$-morpholino $)$ propanesulphonic acid (MOPS) buffer ( $\mathrm{pH} 7$ ). RNA samples were denatured before loading by heating to $65^{\circ} \mathrm{C}$ in $33 \%$ formamide/5\% formaldehyde $/ 20 \mathrm{mM}$ MOPS, cooling on ice and adding glycerol and dyes. After electrophoresis, gels were stained with ethidium bromide $(5 \mu \mathrm{g} /$ $\mathrm{ml}$ ), destained to visualise the $18 \mathrm{~S}$ and 28S RNA bands and then transferred to nylon backed nitrocellulose paper (Hybond C extra) in $20 \times \mathrm{SSC}$. The membrane was baked in a vacuum oven $\left(80^{\circ} \mathrm{C}\right.$ for $\left.2 \mathrm{~h}\right)$ and prehybridized and hybridized as described previously (8). Posthybridization blots were washed under high stringency as described for slot blot analysis.

Probes. The probe used was an 800-bp insert derived from exon 3 of the cloned human POMC gene (9). The $\beta$-actin probe was derived from the cloned chick beta actin cDNA. All probes were labeled using the oligoprimed labeling technique (10) and were purified by passage over Sephadex G-50. Specific activity was usually $10^{9} \mathrm{cpm} / \mu \mathrm{g}$, and all of the labeled probe was used in the hybridization reaction.

Statistical analysis. Results were analyzed by the Student's unpaired $t$ test. Dose response curves were assessed by regression analysis. In some experiments (response to db cAMP) the yield of POMC RNA was low, necessitating pooling of samples from triplicate experiments. In these studies, statistical analysis was therefore not possible.

\section{Results}

Effect of db-cAMP. Incubation of the COR L24 cell line with $\mathrm{db}$ cAMP $\left(10^{-3} \mathrm{M}\right)$ for 0.5 to $48 \mathrm{~h}$ demonstrated a significant increase in ACTH precursor peptides at 24 and $48 \mathrm{~h}(\sim 1.5$ and twofold higher, respectively). POMC mRNA levels were higher in the db-cAMP treated cells than in the controls at 5, 24, and $48 \mathrm{~h}$ (1.5-, 3-, 4-fold increase, respectively), (Fig. 1).

Effects of bromocriptine on ACTH precursors. COR L24 cells secrete significant levels of ACTH precursor peptides, as it has been previously described $(3,4)$, with relatively small amounts of ACTH 1-39. COR L24 cells were incubated with 0.15-15 $\mu \mathrm{M}$ bromocriptine for $24 \mathrm{~h}$ and ACTH precursor peptide levels were reduced in a dose-dependent manner (Fig. 2), and this was not caused by processing of the precursors to ACTH (data not shown). At the highest dose $(15 \mu \mathrm{M})$, an approximate twofold inhibition of ACTH precursor peptide levels is evident. Although higher concentrations of bromocriptine were cytotoxic, no decrease in cell viability was seen at $15 \mu \mathrm{M}$ bromocriptine.

Specificity of bromocriptine and effect on cAMP. To confirm that the effects of bromocriptine were not caused by cytotoxicity, the highest dose $(15 \mu \mathrm{M})$ was assessed in the COR L103 cell line which secretes both ACTH precursors and estradiol and responds to forskolin with a rise in ACTH precursors. ACTH precursor peptides in the COR L103 cell line decreased from $48 \mathrm{pmol} / \mathrm{mg}$ protein to $20 \mathrm{pmol} / \mathrm{mg}$ protein during $24 \mathrm{~h}$ (Fig. $3 \mathrm{~A}$ ). Estradiol levels in COR L103 cells were unchanged 
A
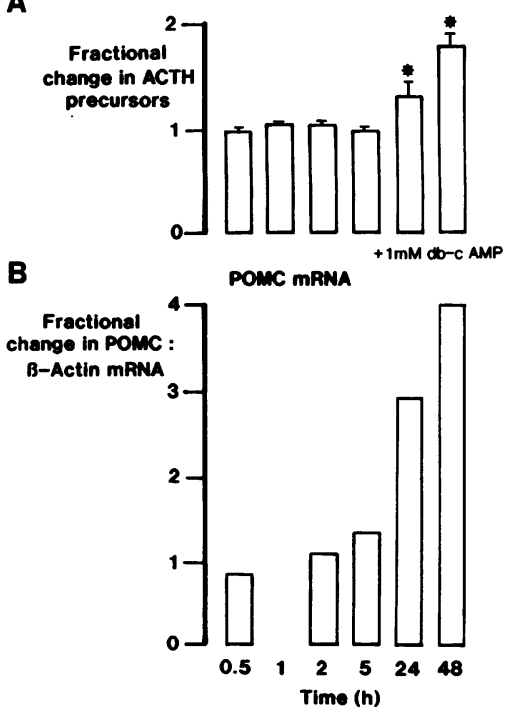

Figure 1. Fractional change in ACTH precursors $(A)$ and POMC mRNA $(B)$ relative to controls at each time point after incubation with $1 \mathrm{mM} \mathrm{db}$ cAMP for the times indicated. Peptide results are the mean $( \pm$ SEM) from three separate experiments. ${ }^{*} P<0.05$. POMC mRNA content is expressed as the fractional change of POMC mRNA densitometric units to the $\beta$-actin mRNA densitometric units relative to the control at each time point (cell pellets com-

bined, data not analyzed statistically). Peptide results are the mean $( \pm$ SEM) of three separate experiments.

in response to bromocriptine (Fig. $3 C$ ), suggesting a specific effect of bromocriptine on ACTH precursors in the SCLC cell line. No inhibition of peptides was evident in the AtT20 cell line (in which POMC is not under dopaminergic control) at 15 $\mu \mathrm{M}$ bromocriptine confirming that this compound had no effect on corticotroph adenoma cells (Fig. $3 \mathrm{~B}$ ). The effects of bromocriptine on cAMP were assessed in COR L103 cells, where cAMP levels decreased from $384 \pm 39 \mathrm{fmol} / \mathrm{mg}$ protein to $237 \pm 12 \mathrm{fmol} / \mathrm{mg}$ protein $P=<0.005$ in the $24 \mathrm{~h}$ postchallenge.

No inhibition of peptide secretion was evident in response to the $\alpha$-adrenoceptor antagonist phenoxybenzamine $(0.29-$ $2.34 \mu \mathrm{M}$ ) during $24 \mathrm{~h}$, while higher doses were cytotoxic (data not shown).

Effect of withdrawal of bromocriptine challenge. Inhibition of ACTH precursors in the $48 \mathrm{~h}$ postchallenge was essentially unchanged (Fig. $4 B$ ) from that seen in the initial $24 \mathrm{~h}$ when the drug was present (Fig. $4 A$ ). Further washing and reculture in fresh media $(24 \mathrm{~h})$ did not result in any recovery of response (data not shown). The initial seeding at high density (neces-

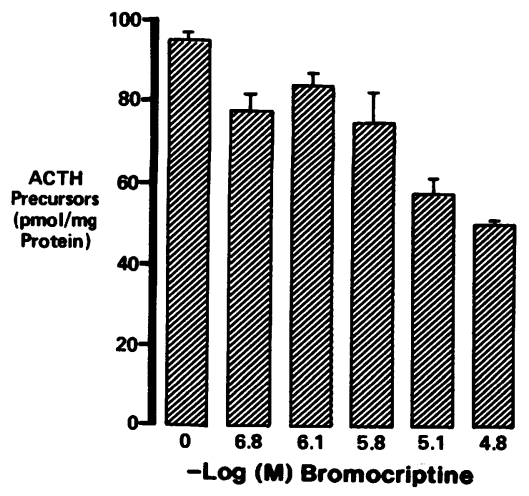

Figure 2. Concentration of ACTH precursors in culture media of cells (COR L24) incubated with increasing concentrations of bromocriptine for $24 \mathrm{~h}$. Each bar represents the mean $( \pm$ SEM) of precursor concentrations expressed per $\mathrm{mg}$ of cell protein from three separate experiments.

Correlation coefficient

$\left(\mathrm{r}_{\mathrm{s}}\right)$ for ACTH precursors was -0.88 . $P \leq 0.001$.
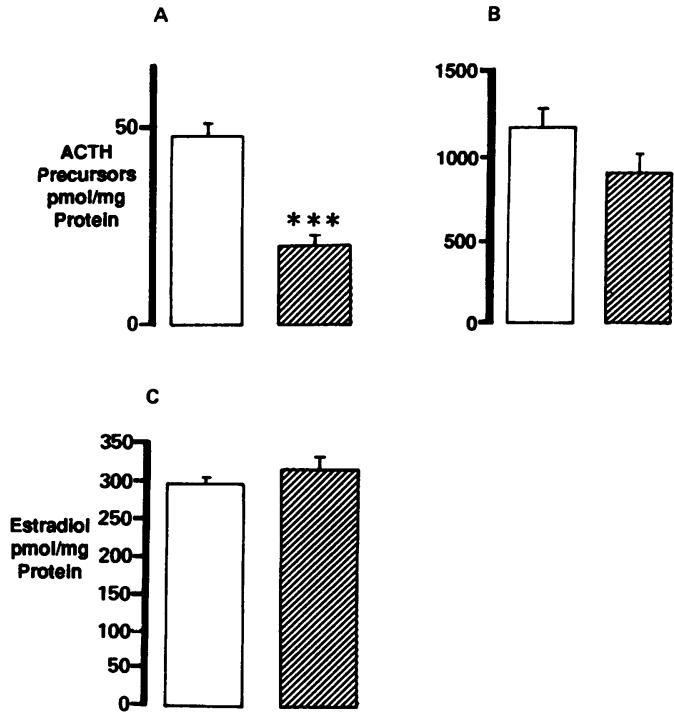

Figure 3. Cells were incubated with bromocriptine for $24 \mathrm{~h}$ and assessed for the concentration of ACTH precursors in media from COR $\mathrm{L} 103(A)$ and AtT20 $(B)$ and for estradiol in COR L103 $(C)$. Each bar represents the mean $( \pm$ SEM) of peptide or steroid concentration expressed per milligram of cell protein from three separate experiments. Clear bars, no bromocriptine; striped bars, $15 \mu \mathrm{M}$ bromocriptine. ${ }^{* * *} P<0.001$.

sary for the detection of measurable peptides) precluded the culture of the COR L103 cell line beyond this time point.

To study the effect of removal of bromocriptine beyond 72 h, cells were seeded at a lower density. From day 3 to day 8 , precursor peptides increased steadily in parallel with control cultures showing a threefold increase over this period. Viable cell counts showed that treated cells achieved $97 \%$ of the density of control cultures $4 \mathrm{~d}$ after removal of the drug.

POMC gene expression. A major POMC-like transcript of $\sim 1,400$ bases and a minor transcript of 3,400 bases was identi-

A COR L103

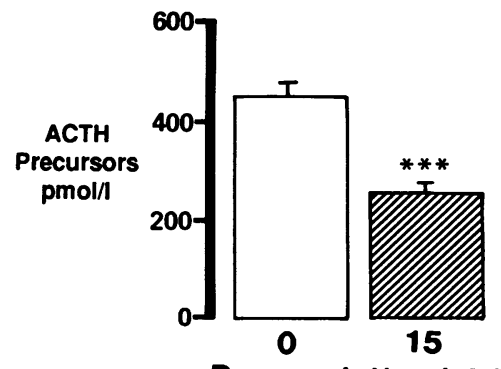

Bromocriptine $(\mu \mathrm{M})$

B COR L103

24h

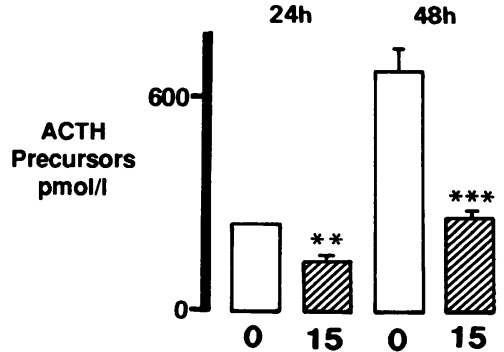

Figure 4. Concentration of ACTH precursors in culture media of COR L103 cells initially incubated with bromocriptine for $24 \mathrm{~h}(A)$, and then washed and sampled after a further 24 $\mathrm{h}$ and $48 \mathrm{~h}(B)$. Clear bars, no bromocriptine; striped bars, $15 \mu \mathrm{M}$ bromocriptine. Each bar represents the mean $( \pm$ SEM) of peptide concentration from three separate experiments. ${ }^{* *} P<0.05$, $* * * P<0.001$. 
fied in the COR L103 cell line by Northern blot analysis (Fig. 5 ). Incubation of the COR L103 cell line with bromocriptine $(15 \mu \mathrm{M})$ for $24 \mathrm{~h}$ caused an approximate threefold decrease in POMC $/ \beta$-actin mRNA ratio (Fig. 6 ). There was no significant difference in $\beta$-actin mRNA levels between control and treated cells and a similar level of suppression was evident for POMC mRNA when data was expressed independently of $\beta$-actin. No inhibition of POMC mRNA or precursor peptides was evident in the control cell line AtT20.

\section{Discussion}

Small cell lung cancer is a disease that retains a very poor prognosis despite recent advances in cancer therapy. One of the characteristics of this tumor are its neuroendocrine features. These include a high frequency of tumors that secrete gastrinreleasing peptide (GRP), the mammalian counterpart of bombesin (11), which has been shown to participate in an autocrine loop, having a trophic effect on tumor cells bearing receptors for this peptide (12).

Expression of the POMC gene and secretion of POMC peptides is a second frequent neuroendocrine association with SCLC. As with GRP, there is evidence that at least one of the peptides derived from POMC, $\beta$-endorphin, also participates

\section{COR L103}

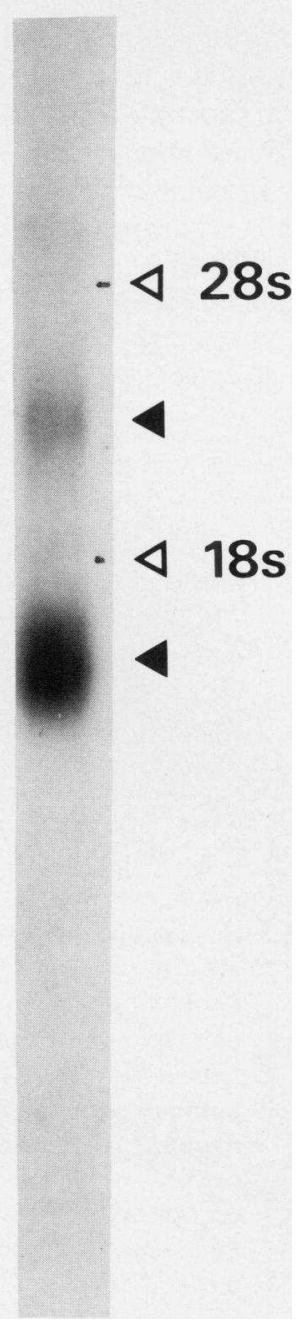

Figure 5. Northern blot hybridization COR L 103 ( $30 \mu \mathrm{g}$ total RNA) exposed for $7 \mathrm{~d}$. Open arrows, $18 \mathrm{~S}$ and 28S ribosomal markers; closed arrows, POMC transcripts.

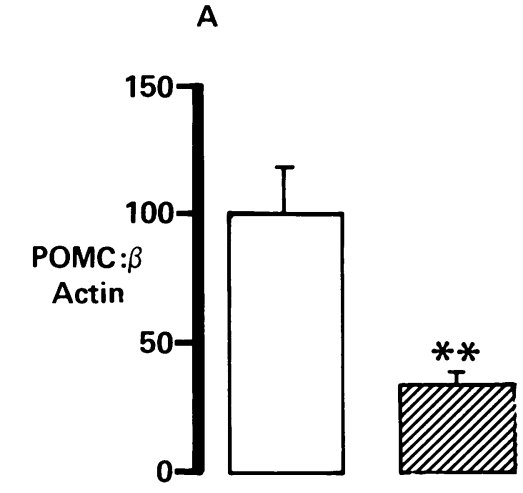

Figure 6. POMC mRNA from $(A)$ COR L103, ( $B$ ) AtT20 after incubation with bromocriptine for $24 \mathrm{~h}$. POMC mRNA content is expressed as the per cent change in the ratio of POMC mRNA densitometric units to the $\beta$-actin mRNA densitometric units. Each bar $( \pm$ SEM) from three separate experiments. Clear bars, no bromocriptine; striped bars, $15 \mu \mathrm{M}$ bromocriptine. ${ }^{* *} P<0.02$, nonstarred bars shown no signifcant change. represents the mean

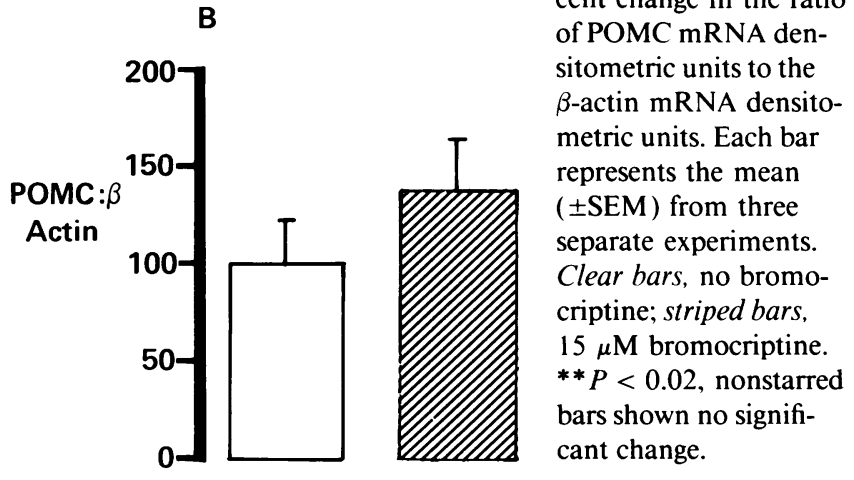

in an autocrine loop in SCLC (13). In addition, POMC expression could also adversely effect the morbidity and mortality associated with this tumor by means of ACTH stimulation of the adrenal cortex. Thus $50 \%$ of patients with SCLC have been found to have elevated cortisol levels (14) and 2.5-7\% have clinically detectable features of the ectopic ACTH syndrome (15). Furthermore, POMC expressing SCLC acts as a model for the ectopic ACTH syndrome resulting from pulmonary tumors. This syndrome remains one of the most clinically trying endocrine conditions, and therefore a significant contribution to the management of these conditions could be made if a means of controlling POMC gene expression were found.

Such an understanding is obviously difficult in patients with SCLC with or without features of glucocorticoid excess, since they are often severely ill on presentation, and therapeutic intervention to treat the tumor cannot be delayed. Several groups have used an approach based on SCLC cell lines in order to try to understand the oncological problems of these tumors. We have used this approach to try to understand some of the endocrine problems of SCLC and have described a SCLC cell line as a model of the ectopic ACTH-secreting tumor, showing that it secretes predominantly POMC precursor peptides (3) and is resistant to glucocorticoid regulation (4), thus mimicking the in vivo situation.

We now report our finding that POMC in these cells is under the positive regulation of cAMP. This is consistent with the regulation of this gene in the corticotroph cells of the anterior pituitary, where the principal stimulator of adenyl cyclase is CRF (16). Gumbiner and Kelly (17) have reported slightly less than a twofold increase in ACTH precursor peptides in the AtT20 cell line after a 90-min exposure to $8 \mathrm{Br}$-c-AMP while "mature" ACTH is stimulated four to fivefold. Using a human SCLC cell line we found a similar increase in ACTH precursors 
evident after $24 \mathrm{~h}$. The failure of the SCLC cell lines to secrete ACTH precludes the studies undertaken by these authors. SCLC tumors are characteristically resistant to CRF, and our findings that this block can be bypassed with db-cAMP suggests that the absence of CRF receptors, or their associated proteins, but not the cyclase enzyme (see below) is the site of this block.

Subsequently, we have sought some means of inhibiting the cAMP signal in these tumors, and have examined the possibility that dopaminergic stimulation through $\mathrm{D}_{2}$ receptors which are linked to $G_{i}$ might achieve this end. We have shown that the $\mathrm{D}_{2}$ agonist bromocriptine, inhibited cAMP production and suppressed ACTH precursor peptide levels in a dose dependent manner without appearing to have any effect on cell viability both in a 24-h and 7-d incubation (data not shown). Multiple hormone secretion by established SCLC cell lines has been reported previously (18) and in these studies the majority of cell lines secrete estradiol. We have exploited this property to compare the effect of bromocriptine on the secretion of ACTH precursors and estradiol. This enabled us to show that bromocriptine specifically suppressed ACTH precursors while estradiol was unaffected. In support of these findings, bromocriptine failed to suppress ACTH precursor peptides in the AtT20 cell line, confirming that there is differential regulation of POMC in corticotroph adenoma cells and SCLC cells. In response to bromocriptine, POMC mRNA was also suppressed whereas no suppression of transcript expression was seen in the AtT20 cell line. Suppression of POMC gene expression relative to the "housekeeping" gene $\beta$-actin further demonstrates that the effects of bromocriptine are specific and not a general down-regulation of transcriptional and translational mechanisms.

Removal of the bromocriptine challenge from the SCLC cells did not result in a recovery of ACTH precursor peptide secretion in the initial $48 \mathrm{~h}$ after washing and incubating cells in fresh medium. When cells were seeded at a lower density postchallenge, peptide output could be monitored over a longer time course. Accumulated peptides detected between day 3 and day 8 increased in parallel with control cultures. In addition, no significant difference in cell number was detected in the $4 \mathrm{~d}$ postchallenge between control and treated cells with a doubling time of $\sim 3.5 \mathrm{~d}$. In our view, the most probable explanation for this prolonged effect of bromocriptine is the low transcriptional rate of the POMC gene in these cells. Circumstantial evidence from other studies with these cells suggests that the POMC mRNA is unusually stable and the db-cAMP studies reported here show that significant changes in POMC mRNA are only apparent after $24 \mathrm{~h}$, even though the transcriptional effect of this second messenger is probably accomplished within a few hours of application. Thus, it seems likely that this mRNA has a low rate of turnover, and this explains our inability to see recovery of mRNA levels within $48 \mathrm{~h}$ of bromocriptine withdrawal in the absence of some positive stimulus. A specific effect on POMC mRNA stability cannot be overruled and has been reported to occur in the rat intermediate lobe (19). Bromocriptine was selected for these studies because it is primarily a $\mathrm{D}_{2}$ agonist that has been used extensively in vivo. It is unlikely that this action is mediated through its well characterized $\alpha$-adrenoceptor antagonism (20), since incubation with the $\alpha$-adrenoceptor antagonist, phenoxybenzamine, did not suppress peptide levels.

Lamberts et al. (21) have reported suppression of ACTH in response to bromocriptine in adenomas of presumed interme- diate lobe origin as judged by the presence within the tumor tissue of argyrophilic fibers. However, a report by Croughs et al. (22) concludes that dopamine responsiveness in patients with Cushing's disease is associated with either corticotroph hyperplasia or a normal pituitary gland and is compatible with a subpopulation of corticotrophs responsive to bromocriptine. McNicol et al. (23) have shown that argyrophilic fibers can be identified not only in corticotroph adenomas adjacent to the posterior lobe, but also in tumors situated deep in the anterior lobe. In vivo suppression of ACTH in response to bromocriptine in one patient with a nonpituitary tumor (lung carcinoid) has been reported previously (24). To our knowledge, with this exception, few studies have addressed the regulation of ACTH and related peptides in nonpituitary tumors. We have approached this problem using an in vitro model of the ectopic ACTH syndrome and find that bromocriptine specifically inhibits POMC gene expression and peptide secretion. In vivo, the effects of bromocriptine and other ergot derivatives on the regulation of cortisol excess and tumor progression should be readily testable. In addition, this drug may prove to have a role in the differential diagnosis of pituitary versus ectopic tumors.

\section{Acknowledgments}

The authors gratefully acknowledge Dr. P. R. Twentyman for the SCLC cell lines used in this study and Dr. Saad Al-Damluji for helpful discussions.

This work was funded in part by the Cancer Research Campaign and the North West Regional Health Authority.

\section{References}

1. Liddle, G. W., W. E. Nicholson, D. P. Island, D. N. Orth, D. K. Abe, and S. C. Lowder. 1969. Clinical and laboratory studies of the ectopic humoural syndromes. Recent Prog. Horm. Res. 25:283-305.

2. Hale, A. C., G. M. Besser, and L. H. Rees. 1986. Characterisation of proopiomelanocortin derived peptides in pituitary and ectopic ACTH secreting tumors. J. Endocrinol. 108:49-56.

3. White, A., M. F. Stewart, W. E. Farrell, S. R. Crosby, P. M. Lavender, P. R. Twentyman, L. H. Rees, and A. J. L. Clark. 1989. Pro-opiomelanocortin gene expression and peptide secretion in human small cell lung cancer cell lines. $J$. Mol. Endocrinol. 3:65-70.

4. Clark, A. J. L., M. F. Stewart, P. M. Lavender, W. E. Farrell, S. R. Crosby, L. H. Rees, and A. White. 1990. Defective glucocorticoid regulation of pro-opiomelanocortin gene expression and peptide secretion in a small cell lung cancer cell line. J. Clin. Endocrinol. Metab. 70:485-490.

5. Orth, D. N., W. E. Nicholson, W. M. Mitchell, D. P. Island, M. Shapiro, and R. L. Byyny. 1973. ACTH and MSH production by a single cloned mouse pituitary tumor cell line. Endocrinology. 92:385-393.

6. Crosby, S. R., M. F. Stewart, J. G. Ratcliffe, and A. White. 1988. Direct measurement of the precursors of adrenocorticotropin in human plasma by twosite immunoradiometric assay. J. Clin. Endocrinol. \& Metab. 67:1272-1277.

7. Chomozynski, P., and N. Sacchi. 1987. Single step method of RNA isolation by acid guanidinium thiocyanate-phenol-chloroform extraction. Anal. Biochem. 162:156.

8. Thomas, P. S. 1980. Hybridization of denatured RNA and small DNA fragments transferred to nitrocellulose. Proc. Natl. Acad. Sci. USA. 77:52015205 .

9. Cochet, M., A. C. Y. Chang, and S. N. Cohen. 1982. Characterisation of the structural, gene and putative 5 '-regulatory sequences for human pro-opiomelanocortin. Nature (Lond.). 297:335-339.

10. Feinberg, A. P., and B. Volgelstein. 1983. A technique for radiolabelling DNA restriction endonuclease fragments to high specific activity. Anal. Biochem. 132:6-13.

11. Pert, C. B., and U. K. Schumacher. 1982. Plasma bombesin concentrations in patients with extensive small cell carcinoma of the lung. Lancet. i:509511.

12. Cuttitta, F., D. N. Carney, J. Mulshine, T. W. Moody, A. Fedorko, A Fischler, and J. D. Minna. 1986. Bombesin-like peptides can function as auto- 
crine growth factors in human small cell lung cancer. Nature (Lond.). 316:823826.

13. Davis, T. P., H. S. Burgess, S. Crowell, T. W. Moody, A. Culling-Berglund, and R. H. Liu. 1989. $\beta$-endorphin and neurotensin stimulate in vitro clonal growth of human SCLC cells. Eur. J. of Pharmacol. 161:283-285.

14. Gilby, E. D., L. H. Rees, and P. K. Bondy. 1975. Ectopic hormones as markers of response to therapy in cancer. Excerpta Med. Int. Congr. Ser. 375:132-138.

15. Kohler, P. C., and D. L. Trump. 1986. Ectopic hormone syndromes. Cancer Invest. 4:543-544.

16. Aguliera, G., P. C. Wynn, J. P. Harwood, R. L. Hauger, M. A. Millan, C. Grewe, and K. J. Catt. 1986. Receptor mediated actions of corticotrophin releasing factor in pituitary gland and nervous system. Neuroendocrinology. 43:79-84.

17. Gumbiner, B., and R. B. Kelly. 1982. Two distinct intracellular pathways transport secretory and membrane glycoproteins to the surface of pituitary tumour cells. Cell. 28:51-59.

18. Sorenson, G. D., O. S. Pettengill, T. Brinck-Johnsen, C. C. Cate, and L. H. Mawer. 1981. Hormone production by cultures of small-cell carcinoma of the lung. Cancer. 47:1289-1296.

19. Pardy, K., D. Carter, and D. Murphy. 1990. Dopaminergic mediation of physiological changes in pro-opiomelanocortin messenger ribonucleic acid ex- pression in the neurointermediate lobe of the rat pituitary. Endocrinology. 126:4 2960-2964.

20. Gibson, A., and M. Samini. 1978. Bromocriptine is a potent $\alpha$-adrenoceptor antagonist in the perfused mesenteric blood vessel of the rat. J. Pharm. Phar macol. 30:314-315.

21. Lamberts, S. W. J., S. De Lange, and S. Z. Stefanko. 1982. Adrenocorticotropin-secreting pituitary adenomas originate from the anterior or the intermediate lobe in Cushing's disease: Differences in the regulation of hormone secretion. J. Clin. Endocrinol. \& Metab. 54:286-291.

22. Croughs, R. J. M., H. P. F. Koppeschaar, J. W. Van'T Verlaat, and A. M McNicol. 1989. Bromocriptine-responsive Cushing's disease associated with anterior pituitary corticotroph hyperplasia or normal pituitary gland. J. Clin. Endocrinol. \& Metab. 68:495-498.

23. McNicol, A. M., G. M. Teasdale, and G. H. Beastall. 1986. A study of corticotroph adenomas in Cushing's disease: no evidence of intermediate lobe origin. Clin. Endocrinol. 24:715-722.

24. Lamberts, S. W. J., J. G. Klijn, M. de Quijada, H. A. Timmermans, P. Vitterlinden, F. H. de Jong, F. H., and J. C. Birkenhäger. 1980. The mechanisms of the suppressive action of bromocriptine on adrenocorticotropin secretion in patients with Cushing's disease and Nelson's syndrome. J. Clin. Endocrinol. \& Metab. 51:307-311. 